\title{
KEEFEKTIFAN PENDEKATAN SAINTIFIK DENGAN KONTEKS ISLAMI DITINJAU DARI LITERASI MATEMATIS SISWA
}

\author{
Rospala Hanisah Yukti Sari \\ Universitas Muhammadiyah Palangkaraya
}

INFO ARTIKEL

Diterima: 5-7-2021

Disetujui: 3-9-2021

\begin{abstract}
Abstrak:
Tujuan penelitian ini adalah untuk mendeskripisikan (1) keefektifan pendekatan saintifik dalam konteks Islami ditinjau dari literasi matematika siswa. (2) keefektifan antara pendekatan saintifik dengan konteks Islami dan pendekatan saintifik ditinjau dari kemampuan literasi matematis siswa kelas VII pada materi aljabar. Jenis Penelitian ini adalah kuasi eksperimen dengan sampel kelas VII MTs Binaul Ummah Bantul. Hasil penelitian ini adalah (1) pendekatan saintifik dengan konteks Islami materi bentuk aljabar secara uji statistik belum efektif, namun mengalami peningkatan rata-rata setelah perlakuan ditinjau dari kemampuan literasi matematika dan kecerdasan emosional siswa kelas VII MTs. (2) Secara uji statistik, pendekatan saintifik dengan konteks Islami tidak lebih efektif dibandingkan dengan pendekatan saintifik ditinjau dari kemampuan literasi matematis siswa kelas VII MTs materi bentuk aljabar. Namun, dengan penerapan pendekatan saintifik dengan konteks Islami dalam pembelajaran dapat menjadi sarana bagi guru untuk memahamkan pengetahuan Islam dan tidak terbatas pada aspek kognitifnya saja
\end{abstract}

Kata Kunci:
Pendekatan Saintifik,
Islami, Literasi
Matematis, Kecerdasan
Emosional

Abstract:

The purpose of this study is to describe (1) the effectiveness of the scientific approach in the Islamic context in terms of students' mathematical literacy. (2) the effectiveness of the scientific approach with the Islamic context and the scientific approach in terms of the mathematical literacy ability of class VII students on algebraic material. This type of research is a quasiexperimental with a class VII sample of MTs Binaul Ummah Bantul. The results of this study are (1) the scientific approach with the Islamic context of algebraic material in statistical tests has not been effective, but has increased in average after treatment in terms of mathematical literacy ability and emotional intelligence of seventh grade students of MTs. (2) In statistical tests, the scientific approach with an Islamic context is not more effective than the scientific approach in terms of the mathematical literacy ability of the VII grade MTs students in algebraic form. However, the application of a scientific approach with an Islamic context in learning can be a means for teachers to understand Islamic knowledge and is not limited to its cognitive aspects

\footnotetext{
Nama $\quad$ : Rospala Hanisah Yukti Sari

Instansi : Universitas Muhammadiyah Palangkaraya

Alamat instansi : Universitas Muhammadiyah Palangkaraya, RTA Milono, KM. 1,5

Surel $\quad$ : rospalahanisah@gmail.com
}

Pentingnya memiliki kemampuan literasi matematis juga diperkuat oleh pendapat Sari \& Wijaya (2017:100) bahwa masyarakat khususnya peserta didik dituntut tidak hanya memahami suatu ilmu pengetahuan, tetapi lebih dalam daripada hal itu yaitu peserta didik mampu menggunakan pengetahuan secara cerdas dan kritis untuk menolak dan memproses informasi yang diperoleh secara optimal sehingga dapat memecahkan masalah yang kompleks. Oleh karena itu, penting dalam memiliki kemampuan mengolah, 
memahami informasi dan pengetahuan serta mampu untuk menganalisis dan menginterpretasikan ilmu dan pengetahuan tersebut, terutama matematika, untuk menghadapi tantangan zaman terutama memecahkan permasalahan yang semakin kompleks ini atau disebut sebagai literasi matematis. Dengan memiliki pemahaman yang baik terhadap matematika, maka dapat membuka kesempatan untuk dapat menyelesaikan berbagai permasalahan. Kohar \& Zulkardi (2014:1) bahwa memiliki pemahaman matematika yang baik memiliki peranan yang penting dalam memecahkan berbagai permasalahan yang kompleks.

Namun fakta yang terjadi, kemampuan siswa dalam literasi matematis siswa juga masih belum menunjukkan hasil yang memuaskan. Hal tersebut dapat diketahui berdasarkan dari penelitian yang dilakukan oleh Siswowijoyo dan Tiya (2014:73) bahwa hasil dari kemampuan literasi matematika siswa SMP Negeri di kota Raha memperoleh persentase rata-rata sebesar $26,27 \%$ dan secara rata-rata siswa hanya mampu menyelesaikan soal literasi kurang dari 50\% dari keseluruhan soal. Hal ini dipengaruhi oleh beberapa faktor, salah satunya adalah kemampuan awal literasi siswa yang masih rendah. Seperti penelitian yang dilakukan oleh Wardono, et al (2018:477) bahwa kemampuan awal literasi matematis siswa SMP berdasarkan pada semua aspek konten sangat rendah, hal ini disebabkan karena pembelajaran di sekolah sekarang berlangsung dengan berorientasi pada buku teks sehingga kemampuan logis, berpikir, analitis, sistematis, kritis dan kreatif kurang ditekankan dan ditingkatkan dalam pembelajaran di sekolah. Dengan demikian, hal tersebut berdampak kepada literasi matematis siswa yang rendah. Hal ini senada dengan hasil penelitian yang dilakukan oleh Mahdiansyah dan Rahmawati (2014:452) bahwa meskipun pada desain internasional yang digunakan telah disesuaikan dengan konteks Indonesia, namun literasi matematika siswa jenjang pendidikan menengah masih rendah. Hasil penelitian tersebut ternyata sama dengan hasil survei lembaga internasional, misalnya PISA.

Berdasarkan Laporan PISA pada Tahun 2015, Indonesia menempati peringkat 63 dari 72 negara dengan skor 386 (OECD, 2016:5). Kemudian didukung oleh laporan Daya Serap Ujian Nasional dari BSNP (INAP, 2015) tentang kemampuan matematika siswa di Indonesia masih terkategori kurang dengan skor kategori kurang sebesar $77,13 \%$, skor terkategori cukup sebesar $20,58 \%$ dan skor terkategori baik sebesar $2,29 \%$. Indikator tersebut dapat terlihat dari proses dan hasil mengajar bahwa komponen-komponen literasi matematis seperti kemampuan memahami, menerjemahkan, menalar, mengomunikasikan, serta keterampilan dalam memecahkan suatu permasalahan yang masih rendah baik dalam bentuk soal rutin maupun non-rutin. Kemudian, siswa masih cenderung pasif sehingga siswa juga kurang terlibat dalam proses pembelajaran. Hal tersebut menyebabkan pembelajaran matematika yang kurang bermakna bagi siswa dan dapat mempengaruhi hasil literasi matematis siswa.

Berdasarkan fakta yang terjadi pada uraian di atas, pembelajaran belum mencapai hasil yang diharapkan. Oleh karena itu, peneliti meragukan dengan penerapan pendekatan saintifik di dalam aktifitas pembelajaran. Oleh karena itu, peneliti mencari alternatif lain dalam aktivitas pembelajaran. Adapun salah satu upaya yang dapat dilakukan untuk melatih kemampuan literasi matematika adalah dengan menambahkan konteks Islami ke dalam pembelajaran pendekatan saintifik. Dengan demikian, upaya yang dilakukan peneliti adalah dengan menerapkan pendekatan saintifik dengan konteks Islami.

Dengan demikian, berdasarkan analisis dari kajian teori dan penelitian yang relevan, diduga bahwa pendekatan saintifik dengan konteks Islami mampu mendukung kemampuan dalam literasi matematika. Berdasarkan uraian yang di atas, penulis tertarik untuk melakukan penelitian dengan berjudul: "Keefektifan Pendekatan Saintifik dengan Konteks Islami ditinjau dari Literasi Matematis"..

\section{METODE PENELITIAN}

Jenis penelitian ini adalah penelitian eksperimen semu (quasi experiment) dengan desain penelitian yang digunakan adalah pre-test post-test control group design. Metode yang digunakan dalam penelitian ini adalah eksperimen dengan teknik analisis kuantitatif. Data dianalisis melalui tahapan : (1) menentukan dua kelas dari satu sekolah masing-masing sebagai kelas eksperimen dan kelas kontrol, (2) memberikan pre-test (test awal) terhadap kedua kelas (3) menerapkan pendekatan saintifik pada kelas kontrol dan pendekatan saintifik dengan konteks Islami pada kelas eksperimen, serta (4) memberikan pos-test (test akhir) terhadap kedua kelas tersebut. Instumen yang digunakan adalah lembar tes, lembar observasi dan angket. Sampel penelitian kelas VII MTs Binaul Ummah Bantul yang dibagi menjadi 2 kelas, yaitu kelas yang bernomor absen genap (kelas eksperimen) dan kelas yang bernomor absen ganjil (kelas kontrol) dengan banyaknya siswa berturut-turut 18 siswa dan 17 siswa. 
Populasi dalam penelitian ini adalah siswa kelas VII MTs Binaul Ummah Bantul. Sedangkan, sampel dalam penelitian ini adalah kelas VII MTs Binaul Ummah Bantul dibagi menjadi 2 kelas, yaitu kelas yang bernomor absen genap (kelas eksperimen) dan kelas yang bernomor absen ganjil (kelas kontrol) dengan banyaknya siswa berturut-turut 18 siswa dan 17 siswa.

Desain penelitian yang digunakan adalah pre-test post-test control group design.Ppeneliti memberikan perlakuan (treatment) kepada dua kelas yang setara atau memiliki karakteristik yang sama. Satu kelas sebagai kelas eksperimen akan diterapkan pendekatan saintifik dengan konteks Islam dan satu kelas lainnya sebagai kelas kontrol akan diterapkan pendekatan saintifik.

Adapun dalam pengumpulan data, penelitian ini menggunakan teknik non tes dan tes sebagai teknik pengumpulan data. Adapun teknik non tes yang dimaksud terdiri dari lembar observasi keterlaksanaan pembelajaran. Sementara itu instrument tes yang digunakan adalah tes kemampuan literasi matematis siswa untuk mengetahui kemampuan literasi matematis siswa dari materi yang telah dipelajari.

Analisis data dalam penelitian ini dilakukan dengan menggunakan teknik analisis data kuantitatif dengan menggunakan pre-test post-test control group design terdiri dari pre-test dan post-test pada kedua kelas. Pre-test digunakan untuk melihat kondisi awal siswa terkait kemampuan literasi siswa sebelum diberikan perlakuan. Sedangkan post-test digunakan untuk melihat kondisi akhir siswa terkait kemampuan literasi siswa setelah diberikan perlakuan.

\section{HASIL PENELITIAN}

Penelitian quasi eksperimen di MTs Binaul Ummah Bantul Di sekolah tersebut hanya terdapat 1 kelas VII dengan banyaknya siswa 35 orang. Oleh karena itu, peneliti membagi banyaknya siswa ke dalam 2 kelas, dengan pembagian menurut nomor absen, yaitu absen ganjil menjadi kelas kontrol dan absen genap menjadi kelas eksperimen dengan banyaknya siswa berturut-turut adalah 18 orang dan 17 orang.

Penelitian ini diawali dengan memberikan soal pre-test untuk mengetahui dan mendeskripsikan data kemampuan awal literasi matematis siswa pada dua kelas penelitian. Pertemuan selanjutnya dilakukan proses pembelajaran sesuai dengan RPP yang telah dirancang untuk masing-masing kelas kontrol dan kelas eksperimen. Adapun materi yang dipelajari dalam penelitian ini adalah bentuk aljabar dengan Kompetensi Dasar (KD) yang telah ditetapkan dalam kurikulum yaitu (a) Menjelaskan bentuk aljabar dan melakukan operasi pada bentuk aljabar (penjumlahan, pengurangan, perkalian, dan pembagian); dan (b) Menyelesaikan masalah yang berkaitan dengan bentuk aljabar dan operasi pada bentuk aljabar. Pembelajaran dilaksanakan selama 4 kali pertemuan sesuai dengan jadwal yang telah ditentukan pada masing-masing kelas. Diakhir penelitian ini, dilaksanakan post-test untuk mendapatkan dan mendeskripsikan data kemampuan literasi matematis setelah pemberian perlakuan. Data keterlaksanaan pembelajaran diperoleh berdasarkan lembar observasi guru dan siswa yang diisi oleh pengamat yaitu guru matematika kelas VII MTs Binaul Ummah Bantul, sedangkan peneliti bertindak sebagai pengajar. Adapun persentase keterlaksanaan pembelajaran berdasarkan lembar observasi kegiatan guru dan siswa pada kelas kontrol secara lengkap disajikan pada Tabel I berikut.

Tabel 1. Persentase Keterlaksanaan Pembelajaran Kelas Kontrol

\begin{tabular}{clcc}
\hline $\begin{array}{c}\text { Pertemuan } \\
\text { ke - }\end{array}$ & Hari/ Tanggal & $\begin{array}{c}\text { Observasi Kegiatan } \\
\text { Guru (\%) }\end{array}$ & $\begin{array}{c}\text { Observasi Kegiatan } \\
\text { Siswa }(\boldsymbol{\%})\end{array}$ \\
\hline $\mathbf{1}$ & Senin, 29 Oktober 2018 & 88 & 85 \\
$\mathbf{2}$ & Jum'at, 2 November 2018 & 92 & 85 \\
$\mathbf{3}$ & Rabu, 7 November 2018 & 92 & 88 \\
$\mathbf{4}$ & Senin, 12 November 2018 & 96 & 92 \\
& Rata-rata & 92 & 87,5 \\
\hline
\end{tabular}

Pada kelas eksperimen, peneliti menggunakan lembar observasi kegiatan guru dan siswa mengikuti alur proses pembelajaran pendekatan saintifik dengan konteks Islami, sedangkan pada kelas kontrol menggunakan pembelajaran dengan pendekatan saintifik.

Adapun persentase keterlaksanaan pembelajaran berdasarkan lembar observasi kegiatan guru dan siswa pada kelas eksperimen secara lengkap disajikan pada Tabel II berikut. 
KARANGAN: Jurnal Kependidikan, Pembelajaran, dan Pengembangan, Vol 03 No 02, Bulan September, Tahun 2021 Hal 79-86

Tabel 2. Persentase Keterlaksanaan Pembelajaran Kelas Eksperimen

\begin{tabular}{clcc}
\hline Pertemuan ke - & \multicolumn{1}{c}{ Hari/ Tanggal } & $\begin{array}{c}\text { Observasi Kegiatan } \\
\text { Guru (\%) }\end{array}$ & $\begin{array}{c}\text { Observasi Kegiatan } \\
\text { Siswa (\%) }\end{array}$ \\
1 & Jum'at, 26 Oktober 2018 & 93 & 88 \\
2 & Rabu, 31 Oktober 2018 & 93 & 92 \\
3 & Senin, 5 November 2018 & 96 & 92 \\
4 & Jum'at, 16 November 2018 & 100 & 96 \\
Rata-rata & 92 & 95,5 & 92 \\
\hline
\end{tabular}

Dari Tabel 9 dan Tabel 10 diperoleh rata-rata persentase observasi kegiatan guru pada kelas eksperimen sebesar 95,5\% lebih tinggi dibandingkan dengan observasi kegiatan guru pada kelas kontrol yaitu sebesar $92 \%$. Kemudian untuk persentase observasi kegiatan siswa pada kelas eksperimen sebesar $92 \%$ lebih tinggi dibandingkan dengan observasi kegiatan guru pada kelas kontrol yaitu sebesar 87,5 \%.

\section{Deskripsi Data}

Deskripsi data bertujuan untuk memperoleh data yang mendukung pembahasan hasil penelitian. Secara umum data dibagi menjadi dua bagian yaitu data sebelum perlakuan dan data setelah perlakuan yang terdiri atas data kemampuan literasi matematis dengan menggunakan pembelajaran dengan pendekatan saintifik dan pembelajaran dengan menggunakan pendekatan saintifik dengan konteks Islami.

Kemampuan Literasi Matematis Siswa

Data kemampuan literasi matematis siswa yang dideskripsikan dalam penelitian ini terdiri dari data kemampuan literasi matematis awal siswa yang diperoleh dari pre-test dan data kemampuan literasi matematis akhir yang diperoleh dari post-test. Pada data kemampuan literasi matematis, skor pre-test digunakan untuk menggambarkan kemampuan literasi matematis siswa sebelum diberikan perlakuan dalam penelitian. Sedangkan, skor post-test diperoleh setelah diberikan perlakuan sebagai gambaran pengaruh dari pembelajaran sesudah dilakukan tindakan penelitian. Adapun deskriptif data kemampuan literasi matematis pada kelas eksperimen dan kelas kontrol disajikan dalam Tabel III.

Tabel 3. Statistik Deskriptif Kemampuan Literasi Matematis Data Pre-Test dan Post-Test pada Kelas Eksperimen dan Kelas Kontrol

\begin{tabular}{|c|c|c|c|c|}
\hline \multirow{3}{*}{ Deskripsi } & \multicolumn{4}{|c|}{ Statistik Deskriptif Data Kemampuan Literasi Matematis } \\
\hline & \multicolumn{2}{|c|}{ Kelas Eksperimen } & \multicolumn{2}{|c|}{ Kelas Kontrol } \\
\hline & Pre-Test & Post-Test & Pre-Test & Post-Test \\
\hline Rata-rata & 19,8 & 27,19 & 13,94 & 19,94 \\
\hline Standar Deviasi & 13,37 & 19,21 & 15,14 & 20,15 \\
\hline Nilai Minimum Ideal & 100 & 100 & 100 & 100 \\
\hline Nilai Minimum & 3 & 10 & 3 & 4 \\
\hline Nilai Maksimum Ideal & 100 & 100 & 100 & 100 \\
\hline Nilai Maksimum & 42 & 75 & 62 & 91 \\
\hline Varians & 178,76 & 369,02 & 229,22 & 406,02 \\
\hline
\end{tabular}

Berdasarkan Tabel III diketahui bahwa nilai pre-test pada kedua kelas eksperimen tidak terdapat siswa yang melampaui kriteria ketuntasan minimal (KKM) kemampuan literasi matematika yang ditentukan yaitu 75. Berbeda setelah diberikan perlakuan, kedua kelas mengalami peningkatan. Hal tersebut dapat dilihat dari peningkatan rata-rata sebesar 27,19 pada kelas eksperimen dan peningkatan sebesar 19,94 pada kelas kontrol.

Peningkatan juga dapat dilihat dari nilai minimum dan nilai maksimum yang diperoleh siswa pada masing-masing kelas. Data yang telah diperoleh akan digunakan untuk pengujian hipotesis guna melihat efektif atau tidaknya pembelajaran pada kedua kelas ditinjau dari kemampuan literasi matematika siswa. Data kemampuan literasi matematika siswa dapat dilihat secara lengkap pada Lampiran K (halaman 407). Adapun hasil dari analisis N-Gain dapat dilihat dalam Gambar 1. 
KARANGAN: Jurnal Kependidikan, Pembelajaran, dan Pengembangan, Vol 03, No 02, Bulan September, Tahun 2021, Hal 79-86

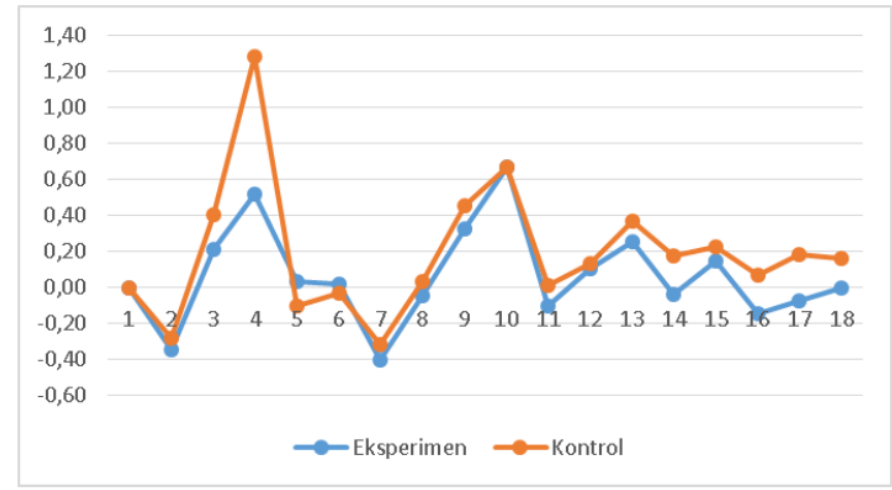

Gambar 1. Diagram garis N-gain Literasi Matematis Siswa

Dari diagram di atas dapat kita lihat N-Gain masing-masing siswa, baik pada kelas kontrol maupun kelas eksperimen. Pada kelas kontrol N-Gain minimum adalah adalah -0,14 sedangkan N-Gain maksimumnya adalah 0,76 sedangkan pada kelas eksperimen $\mathrm{N}$-Gain minimumnya adalah $-0,40$ dan $\mathrm{N}$-Gain maksimumnya adalah 0,67 . Jika dilihat pada nilai $\mathrm{N}$-Gain per siswa pada kelas kontrol lebih tinggi dibandingkan dengan kelas eksperimen. Namun, jika dilihat dalam rata-rata kelas mengalami peningkatan. Adapun distribusi frekuensi dan persentase kemampuan literasi matematis pembelajaran matematika materi bentuk aljabar yang diperoleh dari pre-test dan post-test dapat dilihat pada Tabel 4.

Tabel 4. Distribusi Frekuensi dan Persentase Kemampuan Literasi Matematika Pre-test dan Post-test pada Kelas Eksperimen dan Kelas

\begin{tabular}{|c|c|c|c|c|c|c|c|c|c|}
\hline \multirow{3}{*}{ Interval Skor } & \multirow{3}{*}{ Kriteria } & \multicolumn{4}{|c|}{ Kelas Eksperimen } & \multicolumn{4}{|c|}{ Kelas Kontrol } \\
\hline & & \multicolumn{2}{|c|}{ Pre-test } & \multicolumn{2}{|c|}{ Post-test } & \multicolumn{2}{|c|}{ Pre-test } & \multicolumn{2}{|c|}{ Post-test } \\
\hline & & $\mathbf{F}$ & $\%$ & $\mathbf{F}$ & $\%$ & f & $\%$ & $\mathbf{F}$ & $\%$ \\
\hline$X>80$ & Sangat Tinggi & 0 & 0 & 0 & 0 & 0 & 0 & 1 & 5,55 \\
\hline $60<X \leq 80$ & Tinggi & 0 & 0 & 2 & 12,5 & 1 & 5,88 & 0 & 0 \\
\hline $40<X \leq 60$ & Sedang & 1 & 6,67 & 1 & 6,25 & 0 & 0 & 0 & 0 \\
\hline $20<X \leq 40$ & Rendah & 5 & 33,33 & 6 & 37,5 & 3 & 17,65 & 5 & 27,78 \\
\hline$X \leq 20$ & Sangat Rendah & 9 & 60 & 7 & 43,75 & 13 & 76,47 & 12 & 66,67 \\
\hline
\end{tabular}

Berdasarkan Tabel 4 diketahui bahwa terjadi peningkatan pada kelas eksperimen dan kelas kontrol untuk variabel kemampuan literasi matematika pada materi bentuk aljabar. Pada kelas eksperimen terjadi peningkatan pada kategori tinggi, sedangkan pada kelas kontrol terjadi peningkatan pada kategori sangat tinggi.

\section{Hasil Uji Keefektifan Metode Pembelajaran}

\section{Pendekatan Saintifik dengan Konteks Islami}

Untuk menganalisis keefektifan pembelajaran saintifik dengan konteks Islami ditinjau dari kemampuan literasi matematika dalam pembelajaran matematika materi bentuk aljabar digunakan hasil uji one-sample t-test dengan bantuan software IBM SPSS Statistic 21 terhadap data-data yang diperoleh setelah perlakuan (post-test). Adapun hasil uji one-sample t-test secara rinci dapat dilihat pada Tabel 5.

Tabel 5. Hasil Uji One Sample t-test Kelas Eksperimen

\begin{tabular}{ccc}
\hline Variabel & $\mathbf{T}$ & $\frac{\mathbf{S i g} .}{\mathbf{2}}$ \\
\hline Kemampuan Literasi Matematis & $-9,953$ & 0.000 \\
\hline
\end{tabular}

Berdasarkan Tabel 5, dapat dilihat bahwa $t$ hitung untuk variabel kemampuan literasi matematis lebih kecil dari $t$ tabel $=1,753050$. Hal ini menunjukan bahwa $\mathrm{H}_{0}$ diterima, artinya yaitu pendekatan saintifik 
KARANGAN: Jurnal Kependidikan, Pembelajaran, dan Pengembangan, Vol 03 No 02, Bulan September, Tahun 2021 Hal 79-86

dengan konteks Islami belum efektif ditinjau dari kemampuan literasi matematika dan dalam pembelajaran matematika materi aljabar.

Pendekatan Saintifik

Untuk menganalisis keefektifan pendekatan saintifik ditinjau dari kemampuan literasi matematika siswa dalam pembelajaran matematika materi bentuk aljabar digunakan hasil uji one sample t-test dengan bantuan software IBM SPSS Statistic 21 terhadap data-data yang diperoleh setelah perlakuan (post-test). Adapun hasil uji one-sample t-test secara rinci dapat dilihat pada Tabel 6.

\begin{tabular}{ccc}
\multicolumn{3}{c}{ Tabel 6 Hasil Uji One Sample t-test Kelas Kontrol } \\
\hline Variabel & $\mathbf{T}$ & $\frac{\mathbf{S i g}}{\mathbf{2}}$ \\
\hline Kemampuan Literasi Matematis & $-10,392$ & 0.001 \\
\hline
\end{tabular}

Berdasarkan Tabel 6 diatas, dapat dilihat bahwa $t$ hitung untuk variabel kemampuan literasi matematika lebih kecil dari $\mathrm{t}$ tabel $=1,753050$. Hal ini menunjukan bahwa $\mathrm{H}_{0}$ diterima, artinya yaitu pendekatan saintifik belum efektif ditinjau dari kemampuan literasi matematika dalam pembelajaran matematika materi aljabar.

Hasil Uji Perbedaan Keefektifan Pembelajaran

Uji perbedaan keefektifan pembelajaran dilakukan terhadap data sebelum perlakuan dan data setelah perlakuan pada kedua kelas eksperimen. Uji perbedaan sebelum perlakuan dimaksudkan untuk melihat apakah ada perbedaan antara kedua kelompok sampel sebelum perlakuan dan analisis data setelah perlakuan dimaksudkan untuk melihat apakah terdapat perbedaan keefektifan antara kedua kelompok sampel setelah diberikan perlakuan.

Uji perbedaan keefektifan menggunakan uji MANOVA dengan bantuan software IBM SPSS Statistic 21. Adapun hasil uji perbedaan pembelajaran sebelum perlakuan dapat dilihat pada Tabel 7.

Tabel 7. Hasil Uji Manova Data Sebelum Perlakuan (Pre-Test)

\begin{tabular}{ccc}
\hline Sebelum Perlakuan & F & Sig. \\
\hline Hotelling's Trace & 1,194 & 0,318 \\
\hline
\end{tabular}

Dari Tabel 7 diatas diperoleh hasil bahwa nilai signifikansi F sebelum perlakuan lebih besar dari 0,05 sehingga $\mathrm{H}_{0}$ diterima yang berarti tidak ada perbedaan kemampuan awal siswa antara kelas eksperimen dan kelas kontrol ditinjau dari kemampuan literasi matematika. Kemudian untuk uji perbedaan keefektifan pembelajaran setelah perlakuan pada kedua kelas eksperimen juga menggunakan uji MANOVA dengan bantuan software IBM SPSS Statistic 21. Adapun hasil uji perbedaan pembelajaran setelah perlakuan dapat dilihat pada Tabel 8 .

\begin{tabular}{ccc}
\multicolumn{3}{c}{ Tabel 8. Hasil Uji Manova Data Setelah Perlakuan (Post-Test) } \\
\hline Sebelum Perlakuan & F & Sig. \\
\hline Hotelling's Trace & 1,159 & 0,854 \\
\hline
\end{tabular}

Berdasarkan Tabel 8, diperoleh hasil bahwa nilai signifikansi $\mathrm{F}$ sesudah perlakuan lebih besar dari 0,05. Hal ini menunjukan bahwa diterima yang berarti tidak terdapat perbedaan keefektifan pembelajaran yang diterapkan antara kelas eksperimen dan kelas kontrol ditinjau dari kemampuan literasi matematika.

Hasil Uji Keunggulan Metode Pembelajaran

Tidak terdapat perbedaan keefektifan antara kelas eksperimen dan kelas kontrol ditinjau dari kemampuan literasi matematika, maka tidak dilakukan uji lanjut yaitu uji univariat

\section{PEMBAHASAN}

Perlakuan yang diberikan dalam penelitian ini adalah pendekatan saintifik dengan konteks Islami pada kelas eksperimen, sedangkan pada kelas kontrol hanya diterapkan pendekatan saintifik. Pembelajaran pada kelas eksperimen terdiri dari 18 siswa sedangkan pada kelas kontrol terdapat 17 siswa kelas VII MTs Binaul Ummah Bantul. Sebelum kedua kelas diberikan tindakan penelitian, kondisi awal siswa menunjukan 
KARANGAN: Jurnal Kependidikan, Pembelajaran, dan Pengembangan, Vol 03, No 02, Bulan September, Tahun 2021, Hal 79-86

kemampuan yang sama. Hal ini didukung dari hasil analisis penelitian yang menunjukan bahwa data-data pretest kemampuan literasi matematika siswa yang dihasilkan berdistribusi normal dan homogen.

Dari hasil pre-test kemampuan literasi matematika pada kedua kelas, tidak ada siswa yang mencapai kriteria ketuntasan minimal yang sudah ditentukan yaitu 75 . Hal tersebut wajar terjadi dikarenakan siswa pada kedua kelas belum memiliki pengetahuan sebelumnya terkait materi yang diajarkan.

Kemampuan literasi matematika awal siswa pada kedua kelas pun terlihat hampir sama. Adapun dari hasil diagram N-Gain per siswa pada kemampuan literasi matematis diperoleh bahwa pada kelas kontrol lebih tinggi dibandingkan dengan kelas eksperimen. Namun, jika dilihat dalam rata-rata kelas mengalami peningkatan pada kelas eksperimen. Hal ini terjadi karena sebagian siswa pada kelas eksperimen mengalami penurunan pada post-test..

Adapun hasil uji keefektifan di SPSS pada data setelah perlakuan menunjukan bahwa pendekatan saintifik dengan konteks Islami pada kelas eksperimen dan pendekatan saintifik pada kelas kontrol belum efektif ditinjau dari kemampuan literasi matematika. Sedangkan, jika ditinjau dari banyaknya siswa, pada kelas eksperimen mengalami peningkatan rata-rata setelah diberi perlakuan sebesar 3,634\% dan pada kelas kontrol mengalami penurunan setelah diberi perlakuan sebesar 5,29\%. Hal ini dikarenakan siswa mengalami kesulitan karena siswa kurang dilatih memahami soal dengan bentuk soal cerita dan memuat konteks kehidupan sehari-hari. Berdasarkan pengalaman mengajar, sebagian siswa mengantuk karena mereka bergadang di malam harinya. Oleh karena itu, siswa kurang fokus dalam mengikuti aktivitas pembelajaran.

\section{Simpulan}

Proses memahami konsep oleh siswa Berdasarkan hasil analisis data dan pembahasan, maka dapat disimpulkan beberapa hal yang berkaitan dengan rumusan masalah penelitian:

1. Pendekatan saintifik dengan konteks Islami dalam pembelajaran matematika materi bentuk aljabar secara uji statistik belum efektif, namun mengalami peningkatan rata-rata setelah perlakuan ditinjau dari kemampuan literasi matematika siswa kelas VII MTs.

2. Pendekatan saintifik dalam pembelajaran matematika materi bentuk aljabar secara uji statistik belum efektif, namun mengalami peningkatan rata-rata setelah perlakuan ditinjau dari kemampuan literasi matematika siswa kelas VII MTs.

3. Secara uji statistik, pendekatan saintifik dengan konteks Islami tidak lebih efektif dibandingkan dengan pendekatan saintifik ditinjau dari kemampuan literasi matematika siswa kelas VII MTs dalam pembelajaran matematika materi bentuk aljabar. Namun, dengan penerapan pendekatan saintifik dengan konteks Islami dalam pembelajaran dapat menjadi sarana bagi guru untuk memahamkan pengetahuan Islam dan tidak terbatas pada aspek kognitifnya saja

\section{DAFTAR RUJUKAN}

Asyik, F. M, Ismanto, A. Y \& Babakal, A.(2015). Hubungan Pola Asuh Orang Tua dengan Kecerdasan Emosional pada Anak Usia Remaja Dikelurahan Soasio Kota Tidore Kepulauan. E-Journal Keperawatan (e-Kp), 3(2), 1-6. Retrieved from https://ejournal.unsrat.ac.id/index.php/jkp/article/download/8161/7877.

Cohen, J. (2006). Social, Emotional, Ethical and Academic Education: Creating Climate For Learning, Participation In Democracy and Wellbeing. Harvard Education Review, 71(2), 201-237. Retrieved from www.ijvs.org/files/.../Social,\%20Emotional,\%20Ethical.pdf.

Hawkins, K. B., Florian, L., \& Rouse, M. (2007). Achievement and inclusion in schools. New York: Routledge

INAP. 2018. Laporan Daya Serap Ujian Nasional. Retrieved from http://rekap.kemdikbud.go.id/collectiondetail.php?lang=2\&link=collection\&id=45

Johnston-Wilder, S., Johnston-Wilder, P. \& David, P. (2011). Learning To Teach Mathematics In The Secondary School: A Companion To School Experience. London: Reutledge Taylor and Francis Group. Retrieved from http://oro.open.ac.uk/24160/.Hidayat, A. A., \& Suwandi, A. (2013). Pendidikan anak berkebutuhan khusus tuna netra. Jakarta: Luxima Metro Media. 
KARANGAN: Jurnal Kependidikan, Pembelajaran, dan Pengembangan, Vol 03 No 02, Bulan September, Tahun 2021 Hal 79-86

Kohar \& Zulkardi. (2014). Pengembangan Soal Berbasis Literasi Matematika dengan Menggunakan Kerangka PISA Tahun 2012. Prosiding Konferensi Nasional Matematika XVII. Surabaya: ITS, 379-388. Retrieved

from http://www.academia.edu/12518620/Pengembangan_Soal_Berbasis_Literasi_Matematika_dengan_Mengg unakan_Kerangka_PISA_Tahun_2012.

Mahdiansyah \& Rahmawati. (2014). Literasi Matematika Siswa Pendidikan Menengah: Analisis Menggunakan Desain Tes Internasional Dengan Konteks Indonesia. Jurnal Pendidikan dan Kebudayaan, 20(4), 452-469. Retrieved from http://jurnaldikbud.kemdikbud.go.id/index.php/jpnk/article/view/158.

Organisation for Economic Co-operation and Development (OECD). (2016). PISA 2015 Result in Focus.. Retrieved from https://www.oecd.org/pisa/pisa-2015-results-in-focus.pdf.

Salleh, N \& Othman, I. (2014). The Effects of Integrating Emotional Intelligence on Students ${ }^{\text {ee }}$ Achievement In Mathematics. International Journal of Science Commerce and Humanities, 4(9), 141-149. Retrieved from http://www.aessweb.com/journals/5007.

Sari, R., \& Wijaya, A. (2017). Mathematical Literacy of Senior High School Students in Yogyakarta. Jurnal Riset Pendidikan Matematika, 4(1), 100-107. doi:http://dx.doi.org/10.21831/jrpm.v4i1.10649.

Siswowijoyo, M \& Tiya, K.(2014). Deskripsi Kemampuan Literasi Matematis Siswa Kelas IX SMP Negeri di Kota Raha. Jurnal Penelitian Pendidikan Matematika, 2(2), 73-90. Retrieved From http://ojs.uho.ac.id/index.php/JPPM/article/view/3095/2330

Wardono, Waluya, B, \& Kartono. (2015). The Realistic Scientific Humanist Learning With Character Education To Improve mathematics Literacy Based On PISA. International Journal Of Education And Research., 3(1), 1-10. Retrieved from http://www.ijern.com/journal/2015/January-2015/29.pdf 